\title{
Model team teaching dalam meningkatkan keterampilan sosial anak melalui pemanfaatan lingkungan alam
}

\author{
Mochamad Fatchan Chasani *, Rita Eka Izzaty \\ Universitas Negeri Yogyakarta. Jalan Colombo No.1, Karangmalang, Yogyakarta 55281, Indonesia \\ *Corresponding Author. Email: glendomi@gmail.com \\ Received: 5 August 2018; Revised: 10 November 2018; Accepted: 3 December 2018
}

\begin{abstract}
Abstrak
Tujuan penelitian untuk meningkatkan keterampilan sosial dengan model team teaching melalui pemanfaatan lingkungan alam. Penelitian ini merupakan penelitian tindakan kelas (PTK) dengan subyek 15 anak usia 3-4 tahun di KB Rasi Bintang, Bantul, Yogyakarta. Keabsahan data menggunakan validitas hasil dan proses dengan analisis interaktif yang terdiri atas 3 komponen kegiatan yaitu display data, reduksi data dan pengambilan kesimpulan. Teknik pengumpulan data menggunakan teknik observasi, catatan lapangan, dan analisis dokumen. Hasil penelitian menunjukkan temuan, model team teaching melalui pemanfaatan lingkungan alam mampu meningkatkan keterampilan sosial anak yang meliputi 3 sikap yaitu peduli sebesar $81,2 \%$, kerja sama sebesar $79,8 \%$ dan kemandirian sebesar $80,5 \%$. Model team teaching dilakukan oleh pendidik dengan saling berkontribusi dalam pembelajaran melalui 3 tahapan yaitu perencanaan, pelaksanaan dan evaluasi dengan memadukan potensi lingkungan alam sebagai sumber dan media belajar anak. Proses pembelajaran berlangsung di lingkungan alam mendukung para pendidik dalam memberikan pemahaman, arahan dan pengalaman kepada anak untuk meningkatkan keterampilan sosialnya.
\end{abstract}

Kata Kunci: team teaching, keterampilan sosial, lingkungan alam

\section{Team teaching model in increasing child social skills through utilization of natural environment}

\begin{abstract}
The research aimed in increasing social skills using team-teaching models through utilization of natural environment. This research is a Classroom Action Research (CAR) with subjects who were 15 children aged 3-4 years in KB Rasi Bintang, Bantul, Yogyakarta. The data validity used validity of result and validity of process using interactive analysis that consisted of three activities components namely data display, data reduction, and conclusions drawing. The technique of data collections used were observation, field notes, and document analysis. The research found that the team-teaching model through natural environment utilization can improve the social skills of the children including three attitudes namely caring (81.2\%), cooperation (79.8\%), and independency (80.5\%). The team-teaching model was done by the educators by giving contribution to each other during the learning process through three steps; planning, implementation and, and evaluation. These three steps were done through integration of natural environment potential as the learning source and learning media for the children. The learning process taking place in a natural environment supported the educators to provide understanding, direction and experience to the children in order to improve their social skills.
\end{abstract}

Keywords: team teaching, social skills, natural environment

How to Cite: Chasani, M., \& Izzaty, R. (2019). Model team teaching dalam meningkatkan keterampilan sosial anak melalui pemanfaatan lingkungan alam. JPPM (Jurnal Pendidikan dan Pemberdayaan Masyarakat), 6(1), 76-87. doi:https://doi.org/10.21831/jppm.v6i1.21871

do

https://doi.org/10.21831/jppm.v6i1.21871

\section{PENDAHULUAN}

Keterampilan sosial penting untuk dibelajarkan pada Anak Usia Dini (AUD) (Milyartini, 2016). Hal ini mengacu pada pem- bentukan keterampilan sosial tidak begitu saja tertanam dalam diri anak, namun membutuhkan proses panjang, mengingat AUD berada pada masa tumbuh dan berkembang. 


\section{JPPM (Jurnal Pendidikan dan Pemberdayaan Masyarakat), 6 (1), 2019 - 77 \\ Mochamad Fatchan Chasani, Rita Eka Izzaty}

Proses pembentukan keterampilan sosial anak merupakan wujud nyata dalam mendukung pertumbuhan dan perkembangan anak yang dilakukan melalui penyelenggaraan pembelajaran. Salah satu penyelenggaraan pembelajaran tersebut dilakukan pada satuan atau program pendidikan nonformal seperti Kelompok Bermain (KB) (Menteri Pendidikan dan Kebudayaan Republik Indonesia, 2014).

Anak yang berada pada masa prasekolah seperti di Kelompok Bermain, melakukan proses interaksi yang beragam, baik dengan teman sebaya, pendidik maupun orangtua. Misalnya, anak yang memiliki sikap peduli, dapat bekerjasama dan kemandirian tentu akan lebih mudah dalam menghadapi keberagaman dan dinamika sosial tersebut. Berbagai hasil penelitian telah membuktikan efek dari ada atau tidak adanya keterampilan sosial pada diri anak sejak dini. Setiawan (2016, p. 1) menggambarkan kondisi yang berbeda jika anak-anak belum diajarkan kemampuan interaksi yang baik, maka bisa dipastikan suasana kelas tidak akan kondusif dan akibatnya mengganggu konsentrasi belajar mereka. Hal ini tentu menekankan bahwa kemampuan berinteraksi secara positif sebagaimana keterampilan dan pengetahuan akademik lainnya memiliki andil dalam menentukan keberhasilan anak-anak menjalani kehidupan secara keseluruhan. Seçer, Gülay, Önder, \& Kara (2012, p p.1) menemukan bahwa penelitian tentang keterkaitan antara keterampilan sosial dengan masalah perilaku anak-anak prasekolah menunjukan adanya permasalahan pada tingkat interaksi, kerjasama, masalah perhatian dan agresi.

Hasil pengamatan mendapati adanya masalah pada proses pembelajaran yang belum menunjukan adanya keterlibatan antar pendidik dengan AUD. Aktivitas AUD dalam proses pembelajaran dirasakan belum dapat mengarahkan AUD pada pengembangan sikap, seperti pengembangan sikap berbagi (tempat duduk, mainan, alat gambar), sikap bekerja bersama-sama menyelesaikan tugas kelompok (membuat hasta karya), sikap sabar yang tercermin dalam aktivitas antri, sikap mandiri dalam aktivitas berani tampil di kelas untuk bernyanyi maupun menyampaikan pendapat. Hal ini menjadikan kemampuan AUD kaitannya dengan keterampilan sosial yang ditunjukan melalui sikap berbagi, bekerja sama dan mandiri cenderung lemah. Pengamatan lebih dalam terkait keterampilan sosial yang belum sepenuhnya diajarkan mengarah pada pengelolaan antar pendidik dalam membelajarkan keterampilan sosial pada AUD, padahal KB Rasi Bintang memiliki 2 pendidik (pendidik utama dan pendidik pendamping) untuk melakukan pembelajaran tersebut dalam 1 kelas. Pendidik utama mendominasi perannya dalam menyampaikan materi, sehingga pendidik lainnya yang berperan sebagai pendidik pendamping (co-educator) lebih banyak bertugas mengawasi anak saat pembelajaran berlangsung dan mengikuti perintah dari pendidik utama di dalam proses pembelajaran. Hal ini tentu mengurangi esensi kerjasama antar pendidik dengan tidak adanya timbal balik keduanya seperti saling mengingatkan, memberikan pendapat dan mengatur secara bersama-sama dalam pengelolaan pembelajaran.

Upaya untuk meningkatkan keterampilan sosial anak bukanlah hal yang mudah dan terbentuk secara tiba-tiba, sehingga perlu adanya pemberian ruang kepada anak untuk membiasakan diri, berlatih melalui pembelajaran. Hasil penelitian Kusniapuantari \& Suryono (2014, p.19) mendapati bahwa peran pendidik sangat dibutuhkan untuk perkembangan anak usia dini. Kontak fisik yang dilakukan pendidik melalui bermain akan mendorong perkembangan fisik, kesehatan emosional dan kasih sayang. Fox dan Lentini (2006, p.4) berkesimpulan bahwa para pendidik dapat membimbing anak-anak (prasekolah) untuk mempelajari keterampilan sosial dan emosional melalui cara mengajarnya.

Penelitian oleh Supahar (2009, p. S-8) menyimpulkan bahwa Team teaching menawarkan upaya pembentukan tim atau kelompok di antara pendidik dengan misi utama meningkatkan prestasi siswa dalam belajar. Team teaching juga bermaksud menggagas tentang upaya membangun kebersamaan antara pendidik untuk saling belajar (learning community). Senada dengan itu, Erifiani dan Fauziah (2014, p.16) men- 


\section{JPPM (Jurnal Pendidikan dan Pemberdayaan Masyarakat), 6 (1), 2019 - 78 \\ Mochamad Fatchan Chasani, Rita Eka Izzaty}

jelaskan bahwa kegiatan team teaching dapat memberikan kesempatan pendidik untuk saling menghargai, saling melengkapi dan saling belajar untuk meningkatkan kompetensi masing-masing dalam layanan PAUD, seperti pendidik dapat menjadi pendengar yang baik ketika salah satu rekannya menyampaikan instruksi atau materi, pendidik dapat melengkapi informasi atau ilmu yang belum tersampaikan oleh rekannya dan pendidik dapat belajar memahami kondisi AUD ketika mereka diberi instruksi sehingga dapat belajar mengkondisikan kelas. Di sisi lain, Mannion, Fenwick dan Lynch (2013, p. 792) menyatakan bahwa kolaborasi pendidik dengan memanfaatkan lingkungan alam membuat suasana pembelajaran lebih responsif. Senada dengan itu, Amtorunajah dan Masruri (2015, p. 1) membuktikan bahwa penerapan metode kegiatan di luar kelas (outdoor activity) dapat meningkatkan keterampilan sosial. Oleh karena itu, pembelajaran tim yang dilakukan antar pendidik dapat menciptakan suasana kolaboratif antar pendidik yang dirasa mampu untuk meningkatkan keterampilan sosial anak melalui pemanfaatan lingkungan. Pembelajaran tim dilaksanakan dengan memanfaatkan lingkungan alam sebagai media dan sumber belajar anak untuk meningkatkan keterampilan sosial anak yang meliputi sikap peduli, mandiri dan kerjasama.

\section{METODE}

Penelitian ini merupakan Penelitian Tindakan Kelas (PTK) yang dilakukan di KB Rasi Bintang, Sewon, Bantul dengan sasaran 15 anak usia 3-4 tahun. PTK dilaksanakan untuk meningkatkan keterampilan sosial yang meliputi sikap peduli, kerjasama dan kemandirian dengan model team teaching melalui pemanfaatan lingkungan alam.

Prosedur penelitian yang digunakan mengacu pada proses dasar penelitian tindakan oleh Madya (2011, p. 67) dengan tahapan antara lain: refleksi awal, perencanaan, tindakan, observasi, dan refleksi. Berdasarkan pada prosedur tersebut maka penelitian ini menitikberatkan proses pembelajaran yang dilakukan para pendidik untuk meningkatkan keterampilan sosial anak usia dini.
PTK dilaksanakan dengan melewali 2 siklus, yaitu siklus 1 dan siklus 2, yang sebelumnya diawali adanya prasiklus. Data disajikan dalam bentuk deskripsi yang menjabarkan capaian refleksi pada setiap siklus.

Teknik pengumpulan data menggunakan teknik observasi, catatan lapangan, dan analisis dokumen pembelajaran. Observasi mengacu pedoman observasi yang dilakukan untuk mengamati setiap frekuensi kemunculan sikap sosial pada setiap aktivitas pembelajaran. Aktivitas pembelajaran dilakukan oleh para pendidik yang saling berkolaborasi membentuk sebuah tim pembelajaran (team teaching) dengan memanfaatkan lingkungan alam sebagai sumber dan media pembelajaran untuk meningkatkan 3 sikap sosial anak (peduli, kerjasama dan kemandirian).

Pedoman observasi dibentuk berdasarkan instrumen penelitian yang sebelumnya telah dilakukan validasi oleh 2 dosen ahli dan selanjutnya dilakukan validitas hasil dan validitas proses. Madya (2011, p. 37; pp. 40-41) menjelaskan makna validasi dalam penelitian tindakan berbeda dengan penelitian kuantitatif. Validitas hasil menekankan adanya hasil tindakan yang diperoleh dari setiap refleksi siklus untuk dijadikan acuan baru pada tindakan berikutnya. Sedangkan validitas proses mengacu pada kriteria penelitian tindakan yang memuat adanya suatu keterpercayaan.

Catatan lapangan diperoleh dari hasil pengamatan yang dibuat secara tertulis berbentuk narasi. Catatan lapangan menggambarkan kondisi pembelajaran dan sebagai bentuk refleksi adanya tindakan yang dilakukan. Catatan lapangan memuat aktivitas pembelajaran yang meliputi pembukaan, inti dan penutup pembelajaran. Cakupan dalam aktivitas pembelajaran tersebut menggali 3 aspek kompetensi sikap yaitu sikap peduli, kerjasama dan kemandirian.

Analisis dokumen digunakan untuk menggali berbagai dokumen pembelajaran yang direncanakan dan dibuat. Dokumen pembelajaran meliputi dokumen-dokumen pembelajaran yang terkait dengan keterampilan sosial anak sebelum dilakukannya tindakan dan capaian keterampilan sosial anak. bentuk dokumen pembelajaran antara 


\section{JPPM (Jurnal Pendidikan dan Pemberdayaan Masyarakat), 6 (1), 2019 - 79 \\ Mochamad Fatchan Chasani, Rita Eka Izzaty}

lain Rencana Kegiatan Harian (RKH) dan skenario pembelajaran.

Penelitian ini menetapkan 3 kriteria keberhasilan tindakan sebagai berikut: (1) Model team teaching dapat meningkatkan keterampilan sosial AUD yang meliputi 3 sipak sosial yaitu peduli, kerjasama dan kemandirian melalui pemanfaatan lingkungan alam; (2) Team teaching dilaksanakan melalui 3 tahapan yaitu perencanaan, pelaksanaan dan evaluasi; dan (3) Proses pembelajaran dilakukan melalui pemanfaatan lingkungan alam dengan pemberian pemahaman, arahan dan pengalaman pada AUD.

Teknik analisis data dalam penelitian ini menggunakan analisis data kualitatif dan kuantitatif. Analisis data ditekankan pada refleksi setiap tindakan. Madya (2011, p.75) menjelaskan analisis data diwakili oleh momen rekleksi siklus tindakan dan dilakukan melalui 3 tahapan yaitu reduksi data, display data dan kesimpulan. Pada bagian reduksi data yang diperoleh dari pengamatan, catatan lapangan dan analisis dokumen pembelajaran difokuskan pada 3 bagian yaitu pembukaan pembelajaran, inti pembelajaran dan penutup pembelajaran. Hasil dari reduksi data kemudian ditampilkan melalui display data dalam bentuk tabel dan grafik yang selanjutnya dideskripsikan dan dibuat kesimpulan dengan melibatkan pendidik dan peneliti (inter-rater) yang mengacu pada sumbersumber data.

\section{HASIL DAN PEMBAHASAN}

Penelitian ini dilakukan tindakan dengan 2 siklus. Pelaksanaan tindakan siklus 1 dan siklus 2 didasarkan atas hasil data prasiklus. Pada siklus 1 dan siklus 2 terdapat proses pembelajaran yang meliputi tindakan perencanaan, pelaksanaan, pengamatan dan refleksi. Tindakan siklus 1 dilakukan sebanyak 6 pertemuan pembelajaran di dalam kelas, sedangkan siklus 2 dilakukan sebanyak 2 pertemuan di luar kelas.

Hasil prasiklus yang dilakukan terhadap AUD di KB Rasi Bintang mendapati beberapa anak belum menunjukkan kemampuan sosial. Kemampuan sosial tersebut mencakup beberapa keterampilan atau sikap sosial yang meliputi sikap peduli, kerjasama, dan kemandirian. Sikap peduli yang belum muncul diantaranya perihal kepedulian anak terhadap lingkungan sekitar seperti teman, pendidik dan orangtua maupun lingkungan alam, sehingga berdampak pada cara bersosialisasi anak yang lemah menanggapi segala sesuatu yang ada disekitarnya. Hal ini pula yang berdampak pada kegiatan kelompok yang belum dapat terbangun kerjasama antar AUD, sehingga sikap kerjasama belum nampak pada AUD. Sedangkan sikap kemandirian belum nampak adanya aktivitas mandiri pada pemenuhan kebutuhan pribadi seperti cuci tangan, buang sampah dan kegiatan merapikan media pembelajaran yang sudah digunakannya.

Lebih lanjut, Keterampilan sosial yang belum ditunjukan pada masing-masing anak dapat dilihat dari proses pembelajaran yang dilakukan oleh para pendidik. Pembelajaran yang dilakukan para pendidik masih berorientasi pada pendidik dengan peran pendidik utama yang dominan dalam membawakan materi secara ceramah. Fasilitasi pembelajaran dirasa lemah dalam mendorong AUD meningkatkan keterampilan sosialnya. Pendidik sebatas menggunakan media praktis yang sudah jadi, sehingga pemanfaatan bahan alam sebagai media dan sumber belajar anak belum dilakukan. Selain itu, pengelolaan pembelajaran dan pengkondisian kelas oleh para pendidik belum dilakukan secara optimal.

Pada tahap prasiklus ini diperoleh sikap sosial pada anak usia dini 3-4 tahun di KB Rasi Bintang yang meliputi 3 sikap sosial yaitu peduli, kerjasama dan kemandirian. Ketiga sikap sosial tersebut merupakan hasil observasi yang menunjukan frekuensi kemunculan sikap sosial. Adapun hasil perolehan sikap sosial pada masing-masing subyek penelitian ditunjukan pada Tabel 1.

Berdasarkan table 1 diketahui nilai frekuensi kemunculan masing-masing sikap sosial untuk sikap peduli 31,6\%, kerjasama 31,1\% dan kemandirian 29,8\%. Perolehan tersebut menggambarkan keterampilan sosial pada ketiga sikap sosial tersebut berada pada tingkatan di bawah 50\%.

Keterampilan sosial tersebut belum meningkat disebabkan adanya faktor pendidik dalam membelajarkan keterampilan sosial yang belum dilakukan secara optimal. 


\section{JPPM (Jurnal Pendidikan dan Pemberdayaan Masyarakat), 6 (1), 2019 - 80}

Mochamad Fatchan Chasani, Rita Eka Izzaty

Berikut ini beberapa analisis tentang pembelajaran mengenai keterampilan sosial pada tahap prasiklus: (1) Pembelajaran berpusat pada pendidik. Pendidik utama berperan lebih dominan dari pada pendidik pendamping dengan belum adanya kerjasama antar pendidik; (2) Pembelajaran bersifat klasikal menggunakan metode ceramah dengan tidak adanya umpan balik (feedback) pada AUD untuk melakukan diskusi interaktif; (3) Pendidik belum memfasilitasi, mendorong dan memberikan contoh pada AUD dalam upaya memunculkan dan meningkatkan keterampilan sosial pada 3 aspek sikap (peduli, kerjasama, dan kemandirian); (4) Pendidik sebatas menggunakan media yang sudah jadi dalam pembelajaran yang bersifat praktis, sehingga upaya pemanfaatan bahan alam sebagai media dan sumber belajar anak belum dilakukan; dan (5) Pengelolaan pembelajaran dan pengkondisian kelas oleh para pendidik belum dilakukan secara optimal.

Tabel 1. Hasil Observasi Keterampilan Sosial Prasiklus

\begin{tabular}{clccc}
\hline \multirow{2}{*}{ No. } & \multirow{2}{*}{ Nama } & \multicolumn{3}{c}{ Frekuensi Sikap (\%) } \\
\cline { 3 - 5 } & & Peduli & Kerjasama & Mandiri \\
\hline 1. & NP & $\mathbf{2 2}$ & $\mathbf{2 2}$ & $\mathbf{2 0}$ \\
2. & RK & $\mathbf{2 2}$ & $\mathbf{2 1}$ & $\mathbf{1 8}$ \\
3. & AD & $\mathbf{2 8}$ & $\mathbf{2 8}$ & $\mathbf{2 5}$ \\
4. & AS & 31 & 30 & $\mathbf{2 4}$ \\
5. & DS & 31 & 29 & 27 \\
6. & ADN & $\mathbf{2 3}$ & $\mathbf{2 8}$ & $\mathbf{2 8}$ \\
7. & RF & $\mathbf{2 8}$ & $\mathbf{2 9}$ & $\mathbf{2 7}$ \\
8. & RK & 33 & 35 & 36 \\
9. & IR & 33 & 30 & 34 \\
10. & IT & 40 & 31 & 36 \\
11. & MK & 39 & 38 & 39 \\
12. & LF & 40 & 39 & 37 \\
13. & AF & 31 & 31 & 26 \\
14. & ADT & 38 & 42 & 37 \\
15. & TC & 35 & 34 & 34 \\
Rata-rata & 31,6 & 31,1 & 29,8 \\
persentase & & & \\
\multicolumn{7}{c}{ (\%) } & & &
\end{tabular}

Hasil analisis pembelajaran yang terdapat pada tahap prasiklus dapat diidentifikasi sebagai permasalahan yang dapat ditentukan adanya strategi untuk perbaikan pada siklus berikutnya.

Strategi untuk meningkatkan keterampilan sosial di KB Rasi Bintang difokuskan pada pengelolaan pembelajaran yang diran- cang antara peneliti dan pendidik. Kemudian antar pendidik melakukan pembelajaran dengan pola pembelajaran beregu (team teaching). Team teaching menawarkan adanya kolaborasi antar pendidik yang memberikan ruang untuk saling mengisi ide, memberikan arahan dan pengetahuan antar pendidik. Fungsinya sebagai upaya para pendidik dalam membelajarkan keterampilan sosial kepada AUD yang meliputi sikap peduli, kerjasama dan kemandirian. Fox dan Lentini (2006, p.4) menjelaskan bahwa para pendidik dapat membimbing anak-anak (prasekolah) untuk mempelajari keterampilan sosial dan emosional melalui cara mengajarnya. Pembelajaran yang dilakukan akan lebih mampu memfasilitasi anak untuk berperan aktif baik dalam kegiatan individu maupun kelompok dengan adanya metode diskusi interaktif melalui pemanfaatan lingkungan alam.

Siklus I dilaksanakan pada tanggal 8-10 Mei 2017 dan tanggal 15-17 Mei 2017. Tindakan dilakukan terhadap proses pembelajaran yang meliputi perencanaan, pelaksanaan, pengamatan dan refleksi yang didasarkan atas identifikasi permasalahan pada tahap prasiklus. Hasil tindakan diperoleh dari tahapan proses pembelajaran yang digunakan.

Perencanaan tindakan pembelajaran dilakukan oleh para pendidik dengan dorongan dari peneliti untuk menyusun rencana pembelajaran yang meliputi rencana isi (tujuan, materi, metode, alat, dan evaluasi) dan rencana organisasi (prosedur, konten, durasi, dan komposisi pembelajaran). Pada tahap perencanaan ini pula dilakukan penyusunan Rancangan Kegiatan Harian (RKH), skenario pembelajaran, dan penyiapan media serta sumber belajar.

Skenario pembelajaran dan media belajar dirancang dengan memanfaatkan benda alam seperti daun, biji, ranting dan juga didukung cerita bergambar dari benda alam seperti hewan dan tumbuhan. Rancangan dibuat dengan penataan ruang kelas dan desain tempat belajar sesuai dengan tema yang diterapkan. Terdapat 3 tema dan $6 \mathrm{sub}$ tema yaitu lingkunganku dengan sub tema lingkungan alamku dan benda disekitarku, mengenal benda alam dengan sub tema benda di langit dan benda di bumi dan 


\section{JPPM (Jurnal Pendidikan dan Pemberdayaan Masyarakat), 6 (1), 2019 - 81 \\ Mochamad Fatchan Chasani, Rita Eka Izzaty}

pemanfaatan benda alam dengan sub tema sayur-buah dan tumbuhan-hewan.

Pelaksanaan pembelajaran siklus I dilakukan dengan alokasi waktu 25 menit/ pertemuan. Para pendidik melaksanakan tindakan pembelajaran secara beregu (team teaching). Pendidik terdiri dari pendidik utama dan pendidik pendamping yang saling berkontribusi dalam pembelajaran tentang keterampilan sosial yang meliputi 3 aspek sikap, peduli, kerjasama dan kemandirian. Selama tindakan pembelajaran berlangsung, peneliti dan pendidik lainnya bertindak sebagai pengamat (observer). Pengamatan difokuskan pada proses kegiatan pembelajaran mulai dari kegiatan pembukaan, inti dan penutup pembelajaran. Pembukaan pembelajaran diawali dengan apersepsi, bercerita dan atau bernyanyi, dan dilanjutkan mengawali materi. Inti pembelajaran dilakukan dengan menyampaikan materi pembelajaran sesuai yang termuat pada RKH disertai pemberian visual/gambar benda-benda alam, menghadirkan beberapa benda alam (daun, biji-bijian, ranting, dan sebagainya) dan aktivitas pembelajaran di alam melalui kegiatan minitrip.

Indikator penelitian meliputi 3 aspek keterampilan sosial yaitu peduli, kerjasama dan kemandirian. Indikator tersebut kemudian dikembangkan menjadi lembar observasi yang digunakan untuk mengukur tingkat keterampilan sosial anak usia 3-4 tahun di KB Rasi Bintang. Indikator yang diterapkan pada siklus I meliputi indikator sikap peduli, yaitu (a) Anak dapat berbagi dengan sesama, (b) Anak memiliki perilaku yang mencerminkan sikap sabar, dan (c) Anak dapat bertoleransi. Indikator sikap kerjasama, yaitu: (a) Anak terlibat aktif dalam permainan kelompok, (b) Anak memahami kepentingan bersama dalam kelompok, dan (c) Anak reaktif dalam kegiatan kelompok. Sedangkan indikator sikap kemandirian, yaitu: (a) Anak memiliki rasa tanggungjawab, (b) Anak menunjukan keberanian, dan (c) Anak yakin pada kemampuan sendiri.

Observasi atau pengamatan yang dilakukan peneliti dan pendidik mengacu pada pedoman observasi dan catatan lapangan. Proses pengamatan berlangsung selama kegiatan berlangsung dengan fokus pada pembelajaran keterampilan sosial yang dilakukan para pendidik melalui pemanfaatan lingkungan alam. Pengamatan dilakukan dengan melihat frekuensi kemunculan dari 3 sikap sosial yaitu peduli, kerjasama dan kemandirian. Sikap yang muncul pada AUD disetiap aktivitas pembelajaran mendapat pantauan sesuai indikator yang telah ditetapkan, misalnya pada saat pendidik memberikan instruksi menyiapkan menyiapkan alat dan bahan alam sesuai kelompoknya, maka akan muncul respon AUD (beberapa AUD mungkin saling bekerjasama, beberapa lainnya mungkin tidak).

Pembelajaran pada siklus I memperoleh hasil bahwa beberapa AUD menunjukan keterampilan sosialnya melalui sikap sosial yang nampak pada setiap aktivitas belajar, misalnya AUD tanggap terhadap setiap instruksi yang diberikan pendidik dengan berani menjawab pada saat pendidik bertanya, AUD berusaha menyelesaikan pekerjaan yang sudah menjadi tugasnya, meskipun tidak sampai tuntas atau sempurna dalam menyelesaikan suatu tugas, dan AUD melihat temannya yang sedang kesulitan dalam mengerjakan tugas yang kemudian membantunya. Hal ini menandakan bahwa secara keseluruhan pembelajaran berjalan lancar dengan keikutsertaan AUD secara aktif yang menunjukan keberanian, tanggungjawab, dan kerjasama. Kemunculan sikap peduli terlihat pada saat AUD membantu teman yang lain dalam menyelesaikan penugasan seperti memberi tahu kepada teman yang masih belum mengenal nama benda alam, misalnya mengenali nama biji jagung, nama daun, dan nama batang pohon. Selain itu, sikap peduli ditunjukan pula pada saat AUD saling bergantian dengan teman dalam menggunakan alat permainan. Sedangkan sikap kerjasama ditunjukan oleh AUD dengan memberikan dorongan pada teman dalam kelompoknya untuk bersama-sama menyelesaikan penugasan. Pada sikap kemandirian ditunjukan pada saat AUD saling berdiskusi, satu sama lain berani menyampaikan dan menceritakan benda alam yang sedang dilihat maupun yang sedang dipegangnya, misalnya AUD menceritakan bahwa dirinya memiliki biji jagung, kacang hijau dan kedelai. Lebih lanjut, AUD juga 


\section{JPPM (Jurnal Pendidikan dan Pemberdayaan Masyarakat), 6 (1), 2019 - 82 \\ Mochamad Fatchan Chasani, Rita Eka Izzaty}

menjelaskan bahwa biji-bijian tersebut didapatinya di dapur rumahnya. Selain itu, saat diskusi berlangsung, salah satu pendidik mengajukan pertanyaan tentang manfaat benda alam sembari menunjukkan pada benda alam yang dimaksud, kemudian ditanggapi oleh AUD dalam bentuk jawaban dan cerita. AUD menjawab benda alam yang ditunjukan dan dimaksud pendidik adalah sebuah daun singkong, meskipun belum sepenuhnya AUD dapat menjelaskan secara jelas mengenai manfaatnya, hanya beberapa AUD yang menambahkan bahwa daun singkong biasa dimanfaatkan untuk dimakan.

Tabel 2. Hasil Observasi Keterampilan Sosial Siklus I

\begin{tabular}{clccc}
\hline \multirow{2}{*}{ No. } & \multirow{2}{*}{ Nama } & \multicolumn{3}{c}{ Frekuensi Sikap (\%) } \\
\cline { 3 - 5 } & & Peduli & Kerjasama & Mandiri \\
\hline 1. & NP & 56 & 45 & 43 \\
2. & RK & 54 & 57 & 52 \\
3. & AD & 62 & 55 & 55 \\
4. & AS & 59 & 55 & 60 \\
5. & DS & 67 & 59 & 63 \\
6. & ADN & 61 & 52 & 61 \\
7. & RF & 58 & 59 & 51 \\
8. & RK & 63 & 59 & 68 \\
9. & IR & 67 & 57 & 60 \\
10. & IT & 68 & 61 & 57 \\
11. & MK & 70 & 74 & 77 \\
12. & LF & 69 & 70 & 70 \\
13. & AF & 54 & 59 & 66 \\
14. & ADT & 85 & 76 & 88 \\
15. & TC & 73 & 62 & 72 \\
\multicolumn{2}{c}{ Rata-rata } & 64,4 & 60 & 62,8 \\
persentase (\%) & & & \\
\hline \multicolumn{5}{c}{}
\end{tabular}

Beberapa AUD yang belum dapat memahami materi pembelajaran terlihat dari respon dan sikap AUD menanggapi instruksi pendidik yang lemah bahkan terkesan acuh. Hal ini menjadi kendala yang dimungkinkan atas faktor terbatasnya benda-benda alam yang digunakan sebagai media dan sumber pembelajaran yang dihadirkan dalam situasi kelas. Berbagai benda-benda alam yang dihadirkan di kelas belum mampu merepresentasikan AUD untuk memahami lingkungan alam, sehingga berdampak kurang maksimalnya AUD memahami dan memperkaya pengetahuan tentang alam. Lebih lanjut, daya serap AUD untuk belajar melalui lingkungan alam dan menerapkan nilai-nilai seperti saling berbagi, peduli, kerjasama dan kemandirian kurang bisa terfasilitasi. Tabel 2 merupakan hasil observasi keterampilan sosial pada siklus I.

Berdasarkan table 2 diketahui nilai frekuensi kemunculan masing-masing sikap sosial untuk sikap peduli $64,4 \%$, kerjasama $60 \%$ dan kemandirian 62,8\%. Perolehan keterampilan sosial pada ketiga sikap sosial tersebut meningkat dari tahap prasiklus. Meskipun telah terjadi peningkatan keterampilan sosial, namun masih ada beberapa hal yang membutuhkan perbaikan. Berikut ini hasil refleksi dan rencana perbaikan yang diperoleh pada siklus I, yaitu (a) proses pengenalan anak dengan alam terkendala dari terbatasnya media dan sumber belajar anak sehingga anak kurang memahami dan menerapkan nilai-nilai pada pribadi anak, (b) pembagian tugas dan kontribusi antar pendidik secara beregu (team teaching) dalam memberikan masukan maupun arahan belum terlihat, dan (c) masih terlihat adanya AUD yang memilih-milih teman dalam berkelompok. Sedangkan rencana perbaikan, yaitu (a) Memperbaiki skenario pembelajaran yang memuat rangkaian kegiatan pembelajaran terkait dengan pembagian tugas antar pendidik dan pengaturan ulang desain pembelajaran dan (b) Melibatkan anak pada pembelajaran dengan memperbanyak diskusi interaktif dan juga melibatkan secara langsung interaksi anak dengan alam melalui kegiatan pembelajaran di luar kelas.

Refleksi dan rencana perbaikan tersebut digunakan untuk tindakan pada siklus II. Poin-poin catatan refleksi dan rencana perbaikan yang diperoleh pada siklus I menjadi fokus dalam perencanaan, pelaksanaan, evaluasi dan refleksi pada siklus II. Hal ini diharapkan dapat mendorong meningkatnya keterampilan sosial anak yang meliputi 3 sikap sosial yaitu peduli, kerjasama dan kemandirian dengan penerapan team teaching melalui pemanfaatan lingkungan alam secara langsung sebagai sumber dan media belajar anak usia dini.

Siklus II dilaksanakan pada tanggal 19 Mei 2017 dan 24 Mei 2017. Tindakan dilakukan terhadap proses pembelajaran yang meliputi perencanaan, pelaksanaan, pengamatan dan refleksi yang didasarkan atas refleksi dan rencana perbaikan pada siklus I. 


\section{JPPM (Jurnal Pendidikan dan Pemberdayaan Masyarakat), 6 (1), 2019 - 83 \\ Mochamad Fatchan Chasani, Rita Eka Izzaty}

Tindakan pada siklus II ini juga didasarkan atas indikator yang masih belum tercapai. Selain fokus pada indikator yang ditetapkan, terdapat acuan terutama untuk pelaksanaan dalam pembelajaran yang dilakukan oleh para pendidik terkait peran dan tanggung jawab pendidik.

Perencanaan tindakan pada siklus II dilakukan dengan RKH yang disesuaikan dengan konteks pembelajaran di lingkungan alam. RKH dirancang dengan memfokuskan pada kegiatan belajar AUD secara langsung di alam. Tahap perencanaan ini, kerjasama antar pendidik dalam pembelajaran ditekankan sebagai bentuk tindakan pembelajaran tim (team teaching). Potensi pendidik dalam membuat rencana kegiatan pembelajaran didayagunakan secara bersama-sama saling berkontribusi untuk membuat pembelajaran dengan tujuan pengembangan keterampilan sosial yang meliputi 3 aspek, peduli, kerjasama dan kemandirian. Pembelajaran AUD di lingkungan alam oleh para pendidik dilakukan saling berbagi peran dan tanggungjawab. Pembelajaran dimulai dari kegiatan awal yang dilakukan oleh pendidik dengan mengucapkan salam, mengkondisikan AUD, dan menjelaskan materi belajar belajar bendabenda alam, kemudian dilanjutkan dengan kegiatan inti dan kegiatan penutup. Kegiatan inti dilakukan pendidik dengan mengkoorinasikan AUD satu sama lainnya untuk memahami dan mencermati setiap instruksi para pendidik. Pada kegiatan ini pula pendidik bertugas dalam memberi penjelasan, arahan, dan penugasan. Pembelajaran diakhiri dengan kegiatan penutup yang memuat aktivitas AUD dalam menyikapi dan memberikan masukan serta simpulan atas materi pembelajaran disertai ulasan dan arahan dari pendidik.

Peran dan tanggung jawab pendidik utama dan pendidik pendamping antara lain, pendidik utama berperan mengelola pembelajaran dengan melihat pada kemampuan AUD sesuai dengan perkembangan usianya. Pengelolaan pembelajaran yang dilakukan pendidik berkenaan dengan pengaturan dan perancangan kegiatan pembelajaran yang tentu juga mengkoordinasikan dengan pendidik pendamping. Selain itu, pendidik utama dalam proses pembelajaran menerap- kan komunikasi santun yang dapat dipahami oleh AUD dan pendidik pendamping, serta menunjukan sikap empati terhadap AUD. Hal ini bertujuan positif dalam membangun hubungan antara AUD dan juga pendidik pendamping sehingga dapat mendukung proses pembelajaran yang lancar sampai pada proses penilaian pembelajaran. Lebih lanjut, pendidik utama bertanggungjawab penuh dalam proses pengembangan potensi AUD melalui sikap reflektif, korektif dan inovatif pada setiap aktivitas pembelajaran. Peran dan tanggung jawab pendidik utama tersebut diperkuat dengan kehadiran pendidik pendamping yang juga berperan melaksanakan pembelajaran yang lebih memastikan bahwa proses pembelajaran dapat berjalan lancar sesuai program pendidikan yang sudah ada, pengasuhan dan perlindungan. Selain itu, pendidik pendamping juga bertanggung jawab dalam melaksanakan penilaian terhadap proses dan hasil pembelajaran.

Skenario pembelajaran siklus II dibentuk dengan konteks pembelajaran di alam. Para pendidik merancang 2 kegiatan pembelajaran di lingkungan alam dengan tema lingkunganku. Kegiatan pembelajaran yang pertama dengan konsep minitrip berkeliling lingkungan desa sekitar dan pembelajaran kedua belajar di alam (kebun binatang). Media dan sumber belajar yang tersedia di alam digunakan para pendidik untuk membelajarkan 3 aspek keterampilan sosial anak (peduli, kerjasama dan kemandirian).

Pelaksanaan pembelajaran siklus II terdiri dari 3 bagian proses pembelajaran, yaitu pembukaan, inti dan penutup. Pada bagian inti terdapat kegiatan pengkondisian, penugasan dan diskusi interaktif dengan melibatkan AUD secara langsung pada situasi alam, seperti AUD dilibatkan langsung pada lingkungan alam melalui proses mengenali benda-benda di alam baik biotik maupun abiotik. Pengamatan memperlihatkan lebih banyak AUD yang dapat menunjukan sikap sosialnya seperti peduli, kerjasama dan kemandirian. Hal ini dikarenakan proses pembelajaran dilakukan dengan mengoptimalkan peran masing-masing pendidik dalam pembelajaran tim (team teaching) untuk memfasilitasi AUD meningkatkan keterampilan sosialnya. Selain itu, keterlibat- 


\section{JPPM (Jurnal Pendidikan dan Pemberdayaan Masyarakat), 6 (1), 2019 - 84}

Mochamad Fatchan Chasani, Rita Eka Izzaty

an langsung para AUD dengan lingkungan alam menyebabkan AUD mampu belajar dan mengambil nilai-nilai untuk diterapkan dalam bentuk sikap. Ditambahkan pula, pada saat pembelajaran kurang kondusif, para pendidik dengan sigap mengambil kendali melalui pengkondisian dengan memberikan tindakan berupa arahan, penguatan dan motivasi kepada AUD.

Keterampilan sosial yang meliputi sikap peduli, kerjasama dan kemandirian pada pembelajaran siklus II mengalami peningkatan dari siklus I. Terjadinya peningkatan tersebut disebabkan dari penerapan team teaching dengan pembagian peran dan tanggung jawab di antara pendidik. Kerjasama keduanya dilakukan pada kegiatan perencanaan, pelaksanaan dan evaluasi. Selain itu, AUD dimunculkan kepekaannya bersamaan dengan penerapan team teaching dalam pembelajaran keterampilan sosial. Tabel 3 merupakan hasil observasi keterampilan sosial pada siklus II.

Tabel 3. Hasil Observasi Keterampilan Sosial pada Siklus II

\begin{tabular}{clccc}
\hline \multirow{2}{*}{ No. } & \multirow{2}{*}{ Nama } & \multicolumn{3}{c}{ Frekuensi Sikap (\%) } \\
\cline { 3 - 5 } & & Peduli & Kerjasama & Mandiri \\
\hline 1. & NP & 79 & 75 & 77 \\
2. & RK & 75 & 73 & 72 \\
3. & AD & 74 & 75 & 75 \\
4. & AS & 76 & 75 & 77 \\
5. & DS & 88 & 81 & 82 \\
6. & ADN & 74 & 76 & 80 \\
7. & RF & 78 & 78 & 75 \\
8. & RK & 84 & 85 & 83 \\
9. & IR & 86 & 84 & 85 \\
10. & IT & 87 & 82 & 81 \\
11. & MK & 85 & 86 & 89 \\
12. & LF & 84 & 84 & 83 \\
13. & AF & 73 & 76 & 75 \\
14. & ADT & 90 & 85 & 91 \\
15. & TC & 85 & 82 & 83 \\
\multicolumn{2}{c}{ Rata-rata } & 81,2 & 79,8 & 80,5 \\
persentase & & & \\
\multicolumn{7}{c}{ (\%) } & & & \\
\hline \multicolumn{5}{c}{}
\end{tabular}

Berdasarkan Tabel 3 diketahui nilai frekuensi kemunculan masing-masing sikap sosial untuk sikap peduli $81,2 \%$, kerjasama $79,8 \%$ dan kemandirian 80,5\%. Perolehan keterampilan sosial pada ketiga sikap sosial tersebut meningkat dari tahap siklus I. Peningkatan tersebut dapat dianalisis melalui pembelajaran yang terjadi pada siklus II, yaitu (a) Pembelajaran keterampilan sosial pada anak usia 3-4 tahun di KB Rasi Bintang dilakukan oleh para pendidik dengan melibatkan AUD berkegiatan di lingkungan alam, sehingga AUD dapat memahami, menyerap dan menerapkan nilai-nilai dari hasil belajar di lingkungan alam, (b) Team teaching dalam meningkatkan keterampilan sosial anak dilakukan oleh pendidik dengan saling berkolaborasi dan menerapkan peran dan tanggung jawab masing-masing, dan (c) Kegiatan kelompok AUD dalam pembelajaran pengembangan keterampilan sosial dilakukan dengan pengkondisian oleh para pendidik yang berperan dalam memberikan pengertian dan arahan kepada AUD, sehingga mampu meminimalisasi timbulnya sikap memilihmilih teman.

Hasil siklus II menunjukan adanya peningkatan signifikan terkait keterampilan sosial yang meliputi sikap peduli, kerjasama dan kemandirian. AUD lebih leluasa berkegiatan di lingkungan alam dengan tidak adanya batasan untuk mengeksplorasi pengetahuan dan kemampuan sosialnya, sehingga kepekaan sosial diri terhadap sekitar dapat muncul.

Lebih lanjut, kemampuan para pendidik dalam mengelola pembelajaran dapat terlihat terutama dari keterlibatan para pendidik dalam pembelajaran. Apabila pada siklus 1, pendidik utama lebih dominan dalam melaksanakan pembelajaran, namun pada siklus 2 nampak adanya kebersamaan antar pendidik (pendidik utama dan pendidik pendamping) dalam melakukan pembelajaran. Hal ini terlihat dari kerjasama yang terbentuk, kemudian adanya saling koreksi (kritik dan saran) dan bahkan munculnya tukar peran dan tanggung jawab dalam pembelajaran.

\section{Pembahasan}

Hasil penelitian tindakan kelas yang dilakukan melalui siklus I dan siklus II didasarkan atas pertimbangan observasi awal pada tahap prasiklus yang memiliki tujuan untuk meningkatkan keterampilan sosial anak usia 3-4 tahun dengan diterapkannya model team teaching melalui pemanfaatan lingkungan alam di KB Rasi Bintang. 


\section{JPPM (Jurnal Pendidikan dan Pemberdayaan Masyarakat), 6 (1), 2019 - 85 \\ Mochamad Fatchan Chasani, Rita Eka Izzaty}

Pada tahap prasiklus dilakukan analisis terhadap proses pembelajaran tentang keterampilan sosial yang berlangsung di KB Rasi Bintang, kemudian dilaksanakan perbaikanperbaikan mengenai pembelajaran yang dituangkan pada tahap siklus I dan secara berkelanjutan pada tahap siklus II. Berikut ini disajikan visualisasi peningkatan keterampilan sosial yang meliputi sikap peduli, kerja sama dan kemandirian.

Gambar 1 menunjukan peningkatan keterampilan sosial anak yang mengacu ratarata persentase kemunculan sikap sosial pada tahap prasiklus, siklus I dan siklus II. Pada tahap prasiklus sebelum dilakukannya tindakan diperoleh rata-rata untuk sikap peduli sebesar 31,6\%, kerjasama 31,1\%, dan kemandirian $29,8 \%$. Pada tindakan di tahap siklus I diperoleh rata-rata untuk sikap peduli sebesar $64,4 \%$, kerjasama $60 \%$ dan kemandirian $62,8 \%$ dan pada tindakan di tahap siklus II diperoleh rata-rata untuk sikap peduli $81,2 \%$, kerjasama 79,8\% dan kemandirian 8o, $5 \%$.

Berdasarkan keseluruhan hasil menunjukkan adanya peningkatan keterampilan sosial dengan diterapkannya model team teaching melalui pemanfaatan lingkungan alam. Team teaching dilaksanakan dengan mengaktifkan fungsi pendidik sebagai penggerak dalam pembelajaran. Selain itu, team teaching juga mendorong setiap pendidik untuk saling mengisi kekurangan dalam pembelajaran. Erifiani dan Fauziah
(2014, p. 16) menjelaskan bahwa team teaching dapat memberikan ruang pada masing-masing pendidik untuk saling menghargai, melengkapi dan belajar, sehingga apabila salah satu pendidik menyampaikan pendapat maka pendidik lain mendengar dengan baik, begitupula para pendidik pada saat mengkondisikan AUD akan lebih memahami dalam memberikan instruksi.

Lebih lanjut, para pendidik tidak hanya aktif dalam pelaksanaan pembelajaran namun terlibat dalam keseluruhan pembelajaran mulai dari tahap perencanaan sampai evaluasi. Pada tahap perencanaan, para pendidik merancang rencana isi dan rencana organisasi. Pada tahap pelaksanaan, para pendidik aktif dalam kegiatan pengembangan keterampilan sosial yang meliputi 3 aspek (peduli, kerjasama dan kemandirian) yang mengacu pada perencanaan pembelajaran.

Ditambahkan pula bahwa para pendidik melaksanakan peran dan tanggung jawab masing-masing dalam proses pembelajaran. Pendidik utama berkewajiban menjelaskan materi pembelajaran, sedangkan pendidik pendamping mengatur proses pembelajaran yang berjalan. Pembelajaran berlangsung dengan disertai adanya tukar pendapat maupun bertukar tindakan, masing-masing pendidik saling mengingatkan dengan memberikan masukan, ide dan bahkan sewaktu-waktu bertukar peran yang bersifat insidental.

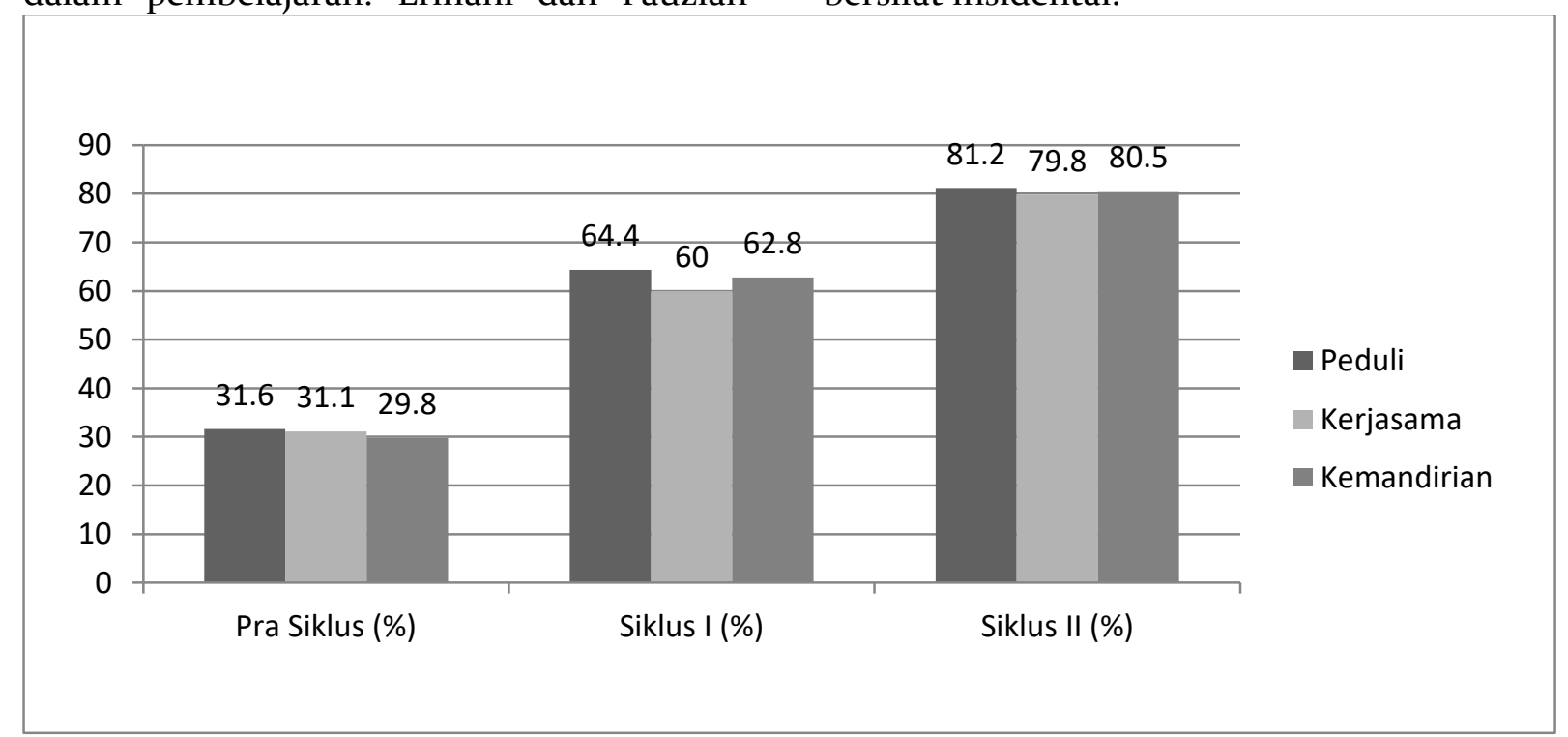

Gambar 1. Persentase Peningkatan Keterampilan Sosial 


\section{Pembelajaran Siklus I dan Siklus II}

Kegiatan pembelajaran siklus I dilakukan pada situasi ruang kelas (indoor), sedangkan siklus II berlangsung pada situasi luar kelas atau di alam (outdoor). Pada situasi ruang kelas, AUD menerima pembelajaran dengan media pembelajaran dari bahan alam yang dihadirkan di kelas. Pendidik utama lebih banyak memberikan penjelasan tentang materi lingkungan alam, sedangkan pendidik pendamping mengawasi jalannya pembelajaran. Materi yang disampaikan pendidik utama berupa kisah tentang tumbuhan dan hewan dengan metode penyampaian ceramah dan sesekali anak turut serta dalam diskusi dalam sesi tanya jawab yang diarahkan oleh pendidik pendamping. Selain itu, bahan alam yang dihadirkan seperti daundaunan, batang pohon, biji-bijian, pasir, tanah, dan batu dijadikan media anak untuk membuat hasta karya.

Pada situasi di luar kelas memiliki aktivitas yang berbeda dengan situasi di dalam kelas, pendidik melibatkan AUD berinteraksi langsung dengan alam yang didalamnya terdapat berbagai benda mati maupun hidup. Proses pembelajaran pun berlangsung di alam terbuka tanpa ada batasan sumber dan media yang dapat dimanfaatkan oleh para pendidik, sehingga para pendidik lebih leluasa dalam memberikan pemahaman, arahan dan pengetahuan kepada AUD. Pada kesempatan tersebut pula, pembelajaran dilakukan di alam terbuka melalui aktivitas outbound. Anak-anak secara berkelompok maupun individu menerima instruksi dari pada pendidik yang langsung dapat dipahami karena didukung adanya interaksi anak dengan benda-benda alam. Hal ini berdampak pada munculnya aktivitas pembelajaran yang lebih dinamis dengan terjadinya komunikasi interaktif antara anak dengan pendidik. Berbagai pertanyaan maupun pendapat disampaikan oleh AUD atas benda-benda alam yang dijumpainya selama pembelajaran berlangsung yang sekaligus para pendidik pun menanggapi dengan memberikan arahan, penguatan dan dorongan pada AUD. Hasil penelitian Mannion, et.al. (2013, p.792) memberikan dukungan bahwa pembelajaran dapat lebih responsif apabila dilakukan kerjasama antar pendidik melalui pemanfaatan lingkungan alam.

Aktivitas AUD yang terlibat langsung dalam pembelajaran di alam memberikan kesempatan secara langsung pada AUD mengolah rasa dan kepekaan terhadap sesama makhluk. AUD lebih cenderung untuk menunjukan keaktifannya saat berada di ruang terbuka dengan disertai arahan para pendidik dalam memberikan materi pembelajaran tentang keterampilan sosial. Masingmasing AUD belajar memahami tentang peristiwa yang ditemui saat berada di lingkungan alam, seperti contohnya padi membutuhkan air untuk tetap hidup dan bebek berbaris rapi mengikuti antrian. Pendidik pun memberikan penjelasan melalui pola refleksi diri, sehingga AUD dapat mengaplikasikan pada dirinya sendiri untuk memiliki sikap-sikap sosial, seperti saling berbagi, peduli, bekerjasama dan juga mandiri dalam kehidupan. Hasil penelitian Amtorunajah dan Masruri (2015, p. 1) membuktikan bahwa pembelajaran dengan menggunakan metode kegiatan di luar kelas (outdoor activity) dapat meningkatkan keterampilan sosial.

Penelitian tindakan kelas ini memperoleh beberapa hasil temuan penelitian. Temuan penelitian berkaitan dengan ketercapaian hasil penelitian, namun tidak hanya itu, pada temuan penelitian ini terdapat beberapa hal yang diperoleh dari hasil penelitian. Berikut ini temuan penelitian yang diperoleh. (1) Model team teaching yang dilakukan dapat mengaktifkan fungsi pendidik dalam kegiatan perencanaan, pelaksanaan, dan evaluasi; (2) Aktivitas AUD di lingkungan alam memberi dampak langsung pada AUD untuk mengolah rasa, kepekaan sosial dan meningkatkan keterampilan sosial yang meliputi sikap peduli, kerjasama dan mandiri; (3) Para pendidik saling berkolaborasi dan bertukar peran dalam memberikan pemahaman, arahan dan pengalaman pada AUD yang ditunjukan dengan kemampuan pengorganisasian pembelajaran; (4) Faktor teman sebaya dan lingkungan alam menjadi pengaruh pada AUD dalam belajar, sehingga AUD yang belum menunjukan keterampilan sosialnya terpacu oleh temanteman dan lingkungan alam untuk dapat bersikap sesuai dengan yang dicontohkan. 


\section{JPPM (Jurnal Pendidikan dan Pemberdayaan Masyarakat), 6 (1), 2019 - 87 \\ Mochamad Fatchan Chasani, Rita Eka Izzaty}

\section{SIMPULAN}

Model team teaching yang diterapkan dengan melibatkan anak dalam memanfaatkan lingkungan alam untuk meningkatkan keterampilan sosial (peduli, kerjasama dan kemandirian) dapat berjalan maksimal. Sumber dan media belajar pada anak dapat lebih besar pemanfaatannya pada saat anak belajar di lingkungan alam. Para pendidik melakukan pembelajaran melalui tahap perencanaan, pelaksanaan dan evaluasi dengan dapat memfasilitasi dan mengkondisikan pembelajaran, sehingga mampu memberikan pemahaman, arahan, pengalaman dan ruang untuk AUD dapat membelajarkan diri dari hasil melihat dan meniru.

\section{DAFTAR PUSTAKA}

Amtorunajah, A., \& Masruri, M. (2015). Peningkatan keterampilan sosial siswa dalam pembelajaran IPS melalui outdoor activity di SMP Negeri 1 Kaligondang Kabupaten Purbalingga. Harmoni Sosial: Jurnal Pendidikan IPS, 2(1), 1-11. doi:https://doi.org/10.21831/hsjpi.v2i1.4 598

Erifiani, B., \& Fauziah, P. (2014). Keefektifan team teaching pendidik program pendidikan dan pengembangan anak usia dini (PPAUD) di Kabupaten Kulon Progo. JPPM (Jurnal Pendidikan dan Pemberdayaan Masyarakat), 1(1), 1 - 17. doi:https://doi.org/10.21831/jppm.vii1.2 355

Fox, L., \& Lentini, R. H. (2006). "You got it!" Teaching social and emotional skills. YC Young Children, 61(6), 36. Retrieved from

https://challengingbehavior.cbcs.usf.ed u/docs/YouGotIt_Teaching-SocialEmotional-Skills.pdf

Kusniapuantari, D., \& Suryono, Y. (2014). Pengaruh kerja sama antara pendidik dan orangtua terhadap pengembangan kecerdasan emosional anak. JPPM (Jurnal Pendidikan dan Pemberdayaan Masyarakat), $\quad 1(1), \quad 18 \quad$ - 31. doi:https://doi.org/10.21831/jppm.vii1.2 353

Madya, S. (2011). Teori dan praktik penelitian tindakan. Bandung: Alfabeta.

Mannion, G., Fenwick, A., \& Lynch, J. (2013). Place-responsive pedagogy: learning from teachers' experiences of excursions in nature. Environmental Education Research, 19(6), 792-809. https://doi.org/10.108o/13504622.2012.7 49980

Menteri Pendidikan dan Kebudayaan Republik Indonesia. Peraturan menteri pendidikan dan kebudayaan nomor 137 tahun 2014 tentang standar nasional pendidikan anak usia dini, Pub. L. No. 137 (2014).

Milyartini, R. (2016). Meningkatkan keterampilan sosial anak usia dini melalui kegiatan bermain angklung (Penelitian tindakan kelas di TK Laboratorium Percontohan Universitas Pendidikan Indonesia). SWARA, 4(2).

Seçer, Z., Gülay, H., Önder, A., \& Kara, C. (2012). The social skills and problem behaviors comparison of 6-year children who go to state and private preschool education institution. International Online Journal of Primary Education (IOJPE) ISSN: 1300-915X, 2(1).

Setiawan, M. H. Y. (2016). Melatih keterampilan sosial anak usia dini melalui permainan tradisional. Jurnal Dimensi Pendidikan dan Pembelajaran, 4(1), 1-8.

Supahar. (2009). Team teaching: Sebuah strategi untuk membangun learning community. Prosiding Seminar Nasional Penelitian, Pendidikan dan Penerapan MIPA, Yogyakarta 